other stock markets, is to provide a means of buying and selling the debt obligations of governments and commercial companies, essential if lenders are to be persuaded to lend. But stockbrokers, with the help of banks of different kinds, also function as a means of bringing new money into the system, in which respect they function as if they were banks in the more familiar sense. The London stock exchange (like others) sets out to regulate the securities that may be bought or sold and even the terms on which trading is allowed, yet there is no means by which lenders (called investors) can be protected against their own poor judgement (nor should there be). But the unprecendented circumstances in which, later this year, much enlarged stockbroking firms will be fighting each other for business that will not expand overnight to match their ambitions are plainly full of risk; the London stock market (like others) maintains a fund to compensate investors who lose money when stockbrokers fail, but there are plainly arithmetical limits to what the collective power of commission-men can do to safeguard the assets belonging to those on whose behalf they deal.

That is only one of the reasons why the British government should be more active in the regulation of its financial institutions. The issue has been bubbling away for two years, since the publication of the report on the steps needed to safeguard investors by Sir Jim Gower. The government has already created a Securities Investment Board whose function will be to superintend the working of financial institutions other than banks (looked after by the Bank of England), the stock market (which superintends itself) and the Lloyds insurance market (which purports to do the same). While the new board will require all those who take in money to be registered, it will ordinarily agree that groups of like-minded institutions should look after themselves. Similarly, the supervision of ordinary banks by the Bank of England is to be overseen by another new board, but one nominated by the Bank of England itself. Before this intended legislation becomes law, it may easily be amended. It should be toughened, and for a simple reason.

However well-deserved may have been the reputation for probity of past bankers, the sanctions they used to apply to keep each other on the straight and narrow path no longer apply. A fraudster who knows that he can move easily from one financial centre to another will not be much deterred by knowing that he will be disinvited from the better golf clubs in the place at which his activities are first discovered. The financial community in Britain is nevertheless offended that there should be talk of explicit external regulation of its affairs, while the government is over-inclined to listen to these arguments. But in the long run, there will be no alternative to explicit regulation. The British government had better bite that bullet now, before too much damage is done. Financial institutions are too important to the economy to be left solely in the hands of financiers.

\section{OPEC is not yet dead}

The oil producers will now be less powerful unless the oil consumers invite further discomfort.

OPEC, the Organization of Oil Exporting Countries, continues to exist, but only just. That is the simplest reading of the meeting at Geneva early in December, when the member states decided that they could no longer by fiat fix the world price for crude oil. This development has been on the cards for at least the past two years, for as long as OPEC's fixed price has been greater than the price at which oil was to be had on the Rotterdam spot market, and while OPEC members have themselves been selling oil at prices below the official price. So is it possible now to celebrate the end of an awkward period in the affairs of the industrialized West and then to forget?

That is what complacency suggests, but complacency is a poor guide. OPEC came into being a quarter of a century ago because the oil-exporting countries quite rightly tumbled to the fact that they were being exploited. In the 1950 s, crude oil was being taken from Saudi Arabia at less than one US dollar a barrel, of which less than a half found its way to the government of that kingdom. During that period, in the United States, it was necessary artificially to prop up the price of domestically produced oil by means of cumbersome sponsored devices such as the Texas Railroad Commission, a federally sponsored carte. But OPEC showed its strength only in 1969 , when Libya cancelled the concessions previously let to multinational oil companies, and began selling its own oil to those prepared to buy it. From that point, the developments of 1973, when the official price of OPEC's crude oil was multiplied roughly five times, were inevitable. The further but smaller increases of price in 1979, ostensibly compensation for inflation in oil-consuming states, were a proof that OPEC was still in a strong position.

What has happened since was also predictable. In the oilconsuming states, the intensity of energy consumption has decreased steadily and dramatically, partly because of greater efficiency but also because of the changing pattern of goods manufactured in the industrialized West. It could easily come about that energy consumption, and oil consumption in particular, will increase again if economic growth accelerates, but many old inefficient ways have probably gone for good.

But none of this implies that OPEC, too, has gone for good. In the long run, the present period of OPEC's weakness, brought about by the declining demand for oil by the industrialized economies and the success of exploration for oil (at OPEC's high price) elswhere in the world, has been accentuated by the urgent need of some oil-producing governments to maintain their oil revenues at the high levels to which they have been overfortunately accustomed. Iran and Nigeria, importunately compelled to sacrifice their long-term interests for the immediate need for cash, have done as much to weaken OPEC as the compensatory market mechanisms at work elsewhere.

For the years immediately ahead, the course of events is predictable enough. Now that oil prices have fallen (to not much more than $\$ 25$ a barrel or $\$ 175$ a tonne), the incentives to exploration will be diminished (but not much), economic activity in the industrialized economies should be stimulated (but, again, not spectacularly) and the price of oil will find a new level at which the interests of the producers and the consumers are balanced. But further ahead, early in the next century perhaps, there will be a different setting for the oil market. By then, no doubt, there will have been further important discoveries of oil in parts of the world still unexplored, so that the potential membership of OPEC will have been enlarged or at least changed (for some oil producers will also have used up their reserves). Similarly, there may then also be now unexpected developments in energy technology that could have transformed the pattern of consumption. But what will stand out, at the turn of the century, is that Saudi Arabia will almost certainly remain in the unique position it occupies at present, as the country most richly endowed with plentiful reserves of crude oil that differs in the most radical respect from that available elsewhere - its production cost is very much less.

This is the sense in which December's events do not spell the end of OPEC. Even if in the years ahead it is destined to become a not particularly congenial dining club, there is every reason to expect that the market for petroleum will change in such a way that Saudi Arabia will again be in a position to play a leading part in sharpening OPEC's teeth. For the oil consumers, the lesson should be clear. Whatever new discoveries there may be, and whatever the fluctuations of the price of crude oil, there are the strongest strategic reasons for strengthening the influences that have induced the energy economies of the past few years. Artificial restraints are inappropriate, as are subsidies of any kind. The better rationalization of industrial production internationally may be more important. Nobody wants OPEC to become a tyrannical influence on the world economy again, but the safeguards are in the hands of the oil consumers. 